\title{
Amino Acid Substitution in an Amidase Produced by an Acetanilide-utilizing Mutant of Pseudomonas aeruginosa
}

\author{
By P. R. BROWN* AND PATRICIA H. CLARKE \\ Department of Biochemistry, University College, Gower Street, London, WC I $6 B T$
}

(Accepted for publication 8 November I97I)

SUMMARY

Mutants of Pseudomonas aeruginosa were isolated which grew with acetanilide ( $N$-phenylacetamide) as the sole carbon source for growth. The mutants could also use acetanilide as a nitrogen source but grew better in the presence of ammonium salts. The acetanilide-utilizing mutants produced amidases which differed in substrate specificity and electrophoretic mobility from the wild-type $\mathrm{A}$ amidase and the $B$ amidase produced by a butyramide-utilizing mutant. The amidase from one of the acetanilide-utilizing mutants was purified and shown to differ from the wild-type enzyme by the substitution of an isoleucine for a threonine residue.

\section{INTRODUCTION}

The aliphatic amidase (acylamide amidohydrolase, EC. 3.5.1.4), produced by Pseudomonas aeruginosa, hydrolyses short-chain aliphatic amides. The wild-type enzyme (A amidase) exhibits greatest activity with acetamide and propionamide as substrates and these two amides also induce amidase synthesis. With higher-molecular-weight amides, activity is very much lower; the enzyme hydrolyses butyramide at about $2 \%$ of the rate at which it hydrolyses acetamide and activity towards valeramide is only barely detectable. The wild-type strain is unable to grow on butyramide or valeramide. From a constitutive mutant producing wild-type enzyme Brown, Brown \& Clarke (1969) isolated mutants which grew well with butyramide as the carbon source for growth. These mutants were shown to produce an altered amidase (B amidase) with a greater activity towards butyramide than the A amidase. By further mutation strains able to utilize valeramide as a carbon source were obtained. These were a heterogeneous group which produced amidases differing in substrate specificity from both the $\mathrm{A}$ and $\mathrm{B}$ amidases.

Many $N$-substituted amides are non-substrate inducers of amidase synthesis for the wildtype strain but acetanilide ( $N$-phenylacetamide) is neither a substrate nor inducer of the enzyme. We have now isolated mutants which are able to utilize acetanilide as a carbon source. The amidase produced by one of these mutants has been purified and compared with the wild-type $\mathrm{A}$ amidase and the $\mathrm{B}$ amidase produced by one of the butyramideutilizing mutants.

\section{METHODS}

Organisms. The bacterial strains used are listed in Table I. The symbols for genotype and phenotype are in accordance with the system proposed by Demerec, Adelburg, Clark \& Hartman (1966). The numbering of the strains in our collection has been changed to a

* Present address: Department of Molecular Biology, University of Edinburgh. 
Table I. Strains of Pseudomonas aeruginosa: genotypes and phenotypes

\begin{tabular}{|c|c|c|}
\hline New strain no. & Old strain no. & Genotype* \\
\hline PAC I & 8602 & $a m i R^{+} a m i E^{+} c r p^{+}$ \\
\hline PAC I 42 & L10 & $a m i R 33 a m i E^{+} c r p-7$ \\
\hline PAC 35I & в 6 & amiRIIamiEI $6 c r p^{+}$ \\
\hline $\operatorname{PAC}_{3} 66$ & AI 3 & iiR33at \\
\hline
\end{tabular}

Phenotypic description

* Genotype abbreviations: $a m i R$, amidase regulator gene; $a m i E$, amidase structural gene; crp, gene locus concerned with catabolite repression.

$\dagger$ Other acetanilide-utilizing mutants listed in Table 2.

system compatible with those used for other collections of Pseudomonas mutants (cf. Holloway, I969). In addition, the mutant amidases which permit the utilization of substrate amides unavailable to the parent strains have been allocated letters which denote the new substrate. The enzymes considered in this paper are the wild-type $A$ amidase, the mutant B amidase and an amidase designated AI produced by one of the acetanilide-utilizing mutants.

Media, bacterial growth and preparation of extracts. Solid and liquid media were prepared as described by Brown et al. (1969). Acetanilide plates contained $0 \cdot 1 \%(\mathrm{w} / \mathrm{v})$ acetanilide as carbon source and $0 . \mathrm{I} \%(\mathrm{w} / \mathrm{v})\left(\mathrm{NH}_{4}\right)_{2} \mathrm{SO}_{4}$ as nitrogen source unless otherwise stated in the text. The conditions for bacterial growth and the method used for preparing cell-free extracts were those described by Brown et al. (1969).

Mutagenesis. Treatment with $N$-methyl- $N^{\prime}$-nitro- $N$-nitrosoguanidine (NMG) was performed as described by Brown et al. (1969). For mutagenesis with ethylmethane sulphonate (EMS), Pseudomonas aeruginosa strain PAC 142 was grown overnight in $5 \mathrm{ml}$ nutrient broth, resuspended in $I^{\circ} 5 \mathrm{ml}$ dilution buffer and $0.2 \mathrm{ml}$ of the suspension was plated on each of several acetanilide plates. Filter-paper discs soaked in EMS were placed in the centre of the plates. Mutant colonies were excised from the plates after 7 days of incubation at $37^{\circ}$. To eliminate contamination by parental bacteria, the mutants were reisolated on acetanilide plates.

Enzyme assays. Assays for amide hydrolase and acyl transferase activities were performed as described by Brown et al. (1969).

Estimation of protein. Protein was estimated by the method of Lowry, Rosebrough, Farr \& Randall (I95I) using bovine plasma albumin as a standard.

Enzyme purification. The AI amidase was purified by the procedure described by Brown et al. (1969) for the wild-type and mutant B amidases but with two modifications. The heattreatment step was omitted and the whole preparation was done at $4^{\circ}$.

Ultracentrifugation. Sedimentation analyses were performed with a Spinco model E ultracentrifuge. Before running, samples were dialysed against $0.01 \mathrm{M}$-tris buffer $(\mathrm{pH} 7 \cdot 2)$ containing $0.15 \mathrm{M}-\mathrm{KCl}, 0.004 \mathrm{M}-2$-mercaptoethanol and 0.00 I M-EDTA.

Immunodiffusion. Experiments were done in agar gels as described by Brown et al. (I969) using antisera prepared against purified $\mathrm{A}$ and $\mathrm{B}$ amidases.

Performic oxidation. The method of Hirs (1956) was used. Oxidation was for $4 \mathrm{~h}$ at $-10^{\circ}$. Amino acid composition. Quantitative determination of amino acid composition was made using an automatic amino acid analyser (Technicon). Peptide samples were hydrolysed in 
$0.3 \mathrm{ml} 6 \mathrm{~N}$-hydrochloric acid in sealed evacuated tubes at $105^{\circ}$ for $22 \mathrm{~h}$. The acid was removed by rotary evaporation at $40^{\circ}$.

Digestion with proteolytic enzymes. Proteolysis with a mixture of trypsin and chymotrypsin was done by adding a freshly prepared aqueous solution of trypsin (1o $\mathrm{mg} / \mathrm{ml}$ ) to a solution of oxidized protein $(4 \mathrm{mg} / \mathrm{ml})$ in $0.1 \mathrm{M}$-ammonium acetate buffer $(\mathrm{pH} 8.5)$ to give a protein-to-trypsin ratio of $75: \mathrm{I}(\mathrm{w} / \mathrm{w})$. After $2 \mathrm{~h}$ incubation at $37^{\circ}$, chymotrypsin was added to give a protein-to-chymotrypsin ratio of $75: \mathrm{I}(\mathrm{w} / \mathrm{w})$ and incubation was continued for a further $5 \mathrm{~h}$. The solution was freeze-dried and the residue stored at $-30^{\circ}$.

Electrophoresis. Starch-gel electrophoresis and the methods used for staining gel slices for enzyme activity were as described by Brown et al. (1969). High-voltage paper electrophoresis for peptide separations was performed in Varsol-cooled tanks of the Michl (I95I) type. Buffers used were acetic acid + pyridine + water $(0 \cdot 3+\mathrm{IO}+90$ by vol. $), \mathrm{pH} 6 \cdot 5$; acetic acid + pyridine + water ( $\mathrm{IO}+\mathrm{I}+89$ by vol.), $\mathrm{pH} 3.5$; acetic acid + formic acid + water $(8+2+90$ by vol.), $\mathrm{pH} 2 \cdot \mathrm{I}$. External coloured markers (Milstein, 1966) were used to monitor lengths of runs. A water-cooled flat-bed electrophoresis apparatus (Locarte Co., London) was used for separating dansyl amino acids. The buffer used was acetic acid+ water $(20+2500$ by vol. $)$, adjusted to $\mathrm{pH} 4.4$ with pyridine.

Separation of peptides on paper. The proteolytic digest, I to $2 \mathrm{mg}$ in $0 . \mathrm{I} \mathrm{M}$-ammonium hydroxide solution, was applied in a $\mathrm{I} \mathrm{cm}$ band to Whatman $3 \mathrm{MM}$ paper $(70 \times 15 \mathrm{~cm})$. The paper was subjected to electrophoresis at $\mathrm{pH} 6.5$ for $2 \mathrm{~h}$ at $2 \mathrm{kV}$. The band of neutral peptides (located by reference to external markers) was cut out, stitched to a strip of Whatman $3 \mathrm{MM}$ paper $65 \mathrm{~cm}$ long and subjected to electrophoresis at $\mathrm{pH} 3.5$ for $3 \mathrm{~h}$ at $2 \mathrm{kV}$. This strip was then stitched to a full-sized sheet of Whatman 3 MM paper $(54 \times 47 \mathrm{~cm})$ and the peptides were chromatographed using butanol + pyridine + acetic acid + water $(5+5+\mathrm{I}+4$ by vol.) as solvent. Peptides were located by dipping the dried chromatograms in $0.1 \%(w / v)$ ninhydrin in acetone; colour was allowed to develop overnight in a dark room. The strips containing the basic and acidic peptides were also stitched to sheets ( $54 \mathrm{~cm}$ long) of Whatman 3 MM paper. The basic peptides were separated by chromatography in the same manner as the final step for the neutral peptides. The acidic peptides were separated by electrophoresis at $\mathrm{pH} 2 \cdot \mathrm{I}$ for $90 \mathrm{~min}$ at $2 \mathrm{kV}$.

Peptide sequencing. The procedures used were those described by Gray (1967a). The dansyl (I-dimethylaminonaphthalene-5-sulphonyl) method was used for the determination of peptide $N$-termini and for identification of the newly exposed $N$-termini after removal of an amino acid residue by the phenyl isothiocyanate method. Dansyl (DNS) amino acids were identified by two-dimensional chromatography on 'polyamide layers' as described by Woods \& Wang (1967). The identities of DNS-ser and DNS-gly were confirmed by electrophoresis at $\mathrm{pH} 2 \cdot \mathrm{I}$ (Gray, $1967 b)$.

Reagents. Trypsin (DCC-treated) and chymotrypsin were obtained from the Sigma Chemical Co, London. Acetanilide from British Drug Houses Ltd, Godalming, Surrey was recrystallized twice from water. Other amides and reagents used in enzyme assays were recrystallized as described by Brown et al. (1969).

\section{RESULTS}

\section{Isolation of mutants}

The strain chosen as the parent for the isolation of mutants growing on acetanilide ( $N$-phenylacetamide) was Pseudomonas aeruginosa PaC 142. This is a constitutive mutant which is also relatively insensitive to catabolite repression and produces more enzyme than 
other constitutive strains grown on the same carbon source (Con, AmiA, Crp-r). It is also relatively insensitive to repression by butyramide (Brown \& Clarke, 1970), so that it belongs to the group of constitutive butyramide-utilizing mutants producing wild-type A amidase. Kelly \& Clarke (1962) found that acetanilide was not a substrate for the wild-type enzyme and that it repressed amidase induction by the non-substrate inducer $N$-methylacetamide acting as a typical amide analogue repressor (Brammar \& Clarke, 1964). Acetanilide ( $5 \mathrm{mM}$ ) had no effect on the synthesis of the A amidase by strain PAC I42 grown overnight in succinate medium although it did repress amidase synthesis by one of the constitutive strains known to be sensitive to butyramide repression (Brown \& Clarke, 1970).

Mutants were readily isolated on acetanilide plates following treatment of strain PAC 142 with either NMG or EMS. J. L. Betz \& P. H. Clarke (unpublished) have recently isolated mutants able to grow on phenylacetamide and to avoid confusion between the two groups of mutants we refer to the $N$-phenylacetamide-utilizing mutants as the acetanilide, AI group, producing AI-type amidases and to the phenylacetamide-utilizing mutants as the phenylacetamide, $\mathrm{Ph}$ group, producing $\mathrm{Ph}$-type amidases.

The AI mutants formed colonies on acetanilide plates after $48 \mathrm{~h}$ incubation at $37^{\circ}$ but even after many days of incubation colonies did not grow very large. After ro days of incubation the colonies became brown, presumably due to the presence of aniline derivatives. The mutants also grew on agar plates containing acetanilide as sole carbon and nitrogen source although less well than when ammonium sulphate was included in the growth medium. All the mutants grew on succinate + formamide $(\mathrm{S} / \mathrm{F})$ medium, which is the standard medium used for isolation and characterization of constitutive mutants (Brammar, Clarke \& Skinner, 1967). Only one mutant, PAC 370 , grew on butyramide medium after $48 \mathrm{~h}$ incubation at $37^{\circ}$ but some of the others grew slightly after several days of incubation, whereas the parent strain PACI42 grew well on butyramide plates forming large colonies after two days of incubation.

\section{Amidase activities of bacterial suspensions}

The amidase activities of the acetanilide-utilizing mutants and the parent strain were compared after overnight growth in pyruvate and succinate media. The specific activities of the bacterial suspensions measured by the acetamide transferase reaction are given in Table 2. It is clear that the specific activities of all the mutants grown on these carbon sources are lower than those of the parent strain. Of all the carbon sources tested, succinate has been found to give the most, and pyruvate and lactate the least, catabolite repression of amidase synthesis. Strain PAC I42, which is less sensitive to catabolite repression than other constitutive mutants, still produces more amidase in pyruvate than in succinate medium. All the AI mutants had higher enzyme activities after growth in pyruvate medium, and although the ratio of activities obtained with pyruvate and succinate grown cells was variable, this probably reflects the variation which was always obtained in the specific activities of batch cultures grown in this way rather than any significant change in the response to catabolite repression.

\section{Amidase activity of cell extracts}

The A and B amidases catalyse hydrolysis and acyl transfer reactions with amide substrates and with certain aliphatic esters (McFarlane, Brammar \& Clarke, 1965; Brown et al. 1969). The mutation which results in the B amidase having a higher activity towards butyramide also affects its relative activities towards other amide and ester substrates. Specific activity values were determined with various substrates for two mutant strains, PAC366 and PAC 370, and compared with the values obtained for the parent strain PAC I42. 
To eliminate the possibility of permeability alterations accounting for the behaviour of the mutants, measurements were made using cell-free extracts prepared from bacteria grown overnight in $1 \%$ pyruvate medium. The data obtained are shown in Table 3 . The specific activities of the mutant extracts were lower than those of PACI42 for all the reactions except acyl transferase with ethyl acetate as substrate. The most striking differences were observed with acetamide as substrate; for both the acetanilide-utilizing AI mutants the acyl transferase activity was only about $50 \%$ of that for PAC I 42 while the hydrolase activity was less than $20 \%$.

Table 2. Specific acetamide transferase activities of cultures of acetanilideutilizing mutants of Pseudomonas aeruginosa

\section{Carbon source in growth} medium

Strain no.
PAC 142 (parent strain)
PAC 364
PAC 365
PAC 366
PAC 367
PAC 368
PAC 369
PAC 370
PAC 371
PAC 372
PAC 373
PAC 374

$\begin{array}{cr}\text { I \% pyruvate } & \text { I \% succinate } \\ \text { I 20 } & 46 \\ 25 & 5 \\ 30 & 8 \\ 26 & 8 \\ 29 & 10 \\ 25 & \text { I } 2 \\ 24 & 7 \\ 28 & 14 \\ 59 & 7 \\ 30 & 14 \\ 22 & \text { I6 } \\ \text { I5 } & \text { I0 }\end{array}$

Cultures were grown at $37^{\circ}$ with shaking for $16 \mathrm{~h}$. Values given are acetamide transferase units/mg bacteria.

Table 3. Amidase activities of cell-free extracts of Pseudomonas aeruginosa mutant strains

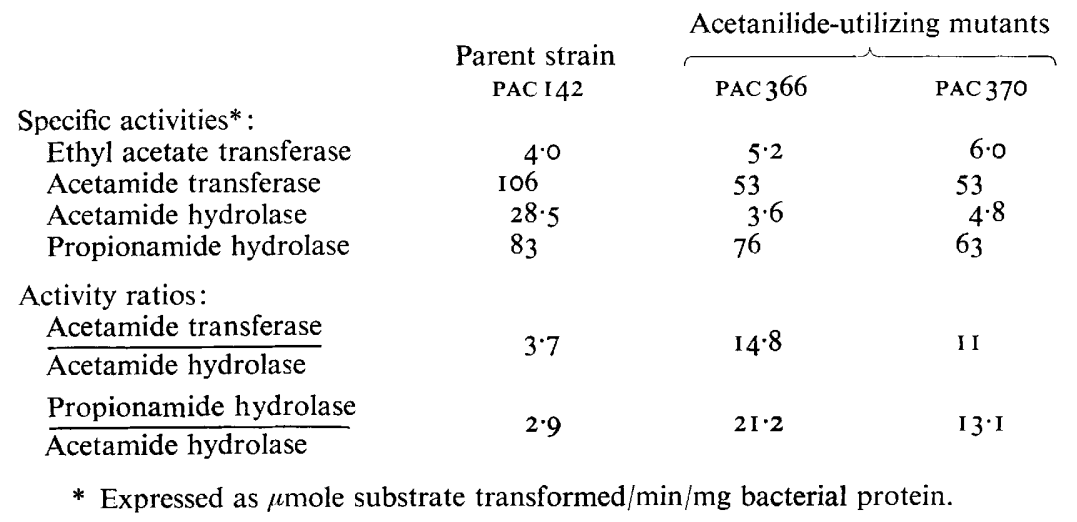

Cell-free extracts prepared from strain PACI42 and from the AI mutants grown in $1 \%$ pyruvate medium were tested for acyl transferase activity with 0.0 I M-acetanilide as substrate. Transferase activity (about $0.6 \%$ of that with acetamide as substrate) was detected using undiluted extracts of all the AI mutants. No activity was detected in the extract from strain PAC I 42. 


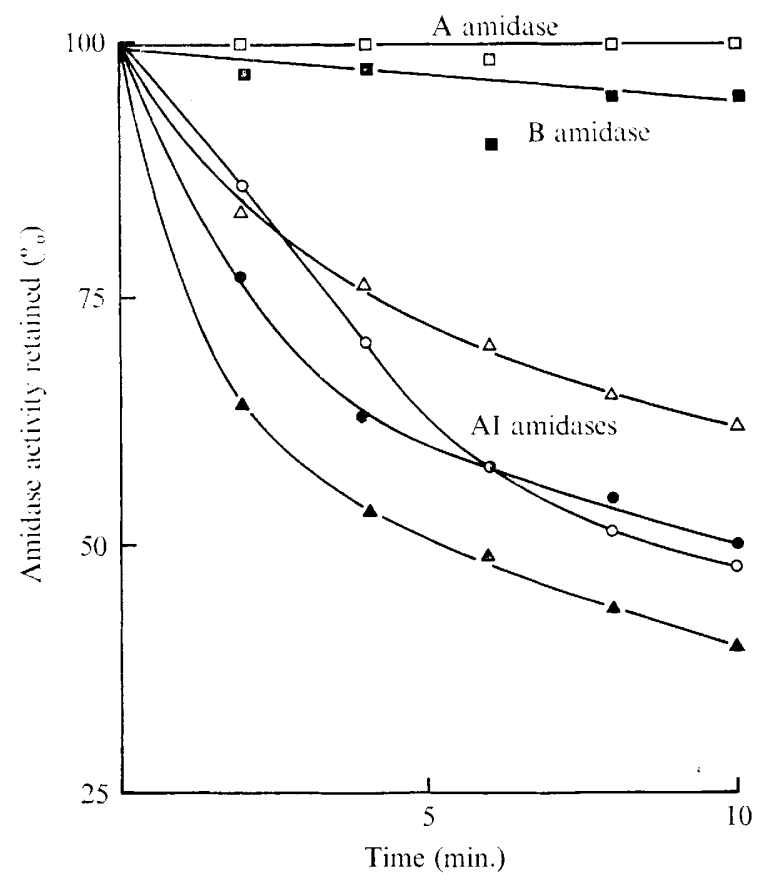

Fig. I. Effect of heating at $57.5^{\circ}$ on activity of wild-type and mutant amidases. $\mathbf{\square}-\mathbf{E}$, purified B amidase; $\Delta-\boldsymbol{\Delta}$, purified AI amidase; $\square-\square$, extract strain PAC I42 (AmiA); $\triangle-\triangle$, extract strain PAC 37 I (AmiAI); O-O, extract strain PAC 365 (AmiAI); - - , extract strain PAC 369 (AmiAI).

\section{Starch-gel electrophoresis of extracts}

Extracts prepared from nine AI mutants were examined by starch-gel electrophoresis at $\mathrm{pH}$ 8.5. After electrophoresis, one slice of the gel was stained for protein and another for transferase activity with acetamide as substrate (Brown et al. 1969). The extracts from all the AI mutants examined in this way gave amidase bands running to the same position on the gel and slightly ahead of the wild-type A amidase band observed in extracts of PAC I42. On gel slices stained for acetamide hydrolase activity, all the AI mutant extracts gave a relatively feeble reaction compared with the PACI 42 extract. This observation indicated that all the AI mutants, in common with PAC 366 and PAC 370, had a much lower acetamide hydrolase activity than the parent strain. A slice of a gel on which extracts of four of the AI mutants and strain PAC I 42 had been subjected to electrophoresis was stained for acyl transferase activity using $0.0 \mathrm{I}$ M-acetanilide as substrate. The PAC I42 extract showed no reaction but extracts of strains PAC 369 , PAC 370, PAC 37I and PAC 372 gave brown bands coincident with their acetamidase bands.

\section{Heat-stability of mutant AI amidases}

The wild-type A amidase suffers no loss of activity if it is maintained at $60^{\circ}$ for $8 \mathrm{~min}$ and a heat-treatment step of this nature is included in the method routinely used for purifying the enzyme (Brown et al. 1969). Fig. I shows a time course of the inactivation of acetamide transferase activity in cell-free extracts of 3 of the AI mutants maintained at $57.5^{\circ}$ for a period of $10 \mathrm{~min}$. The extract most rapidly inactivated was that obtained from strain PAC 366. The amidase from this strain was subsequently purified (see below) and the pure 
Table 4. Purification of AI amidase from Pseudomonas aeruginosa mutant strain $\mathrm{PAC} 366$

Purification was approximately II-fold; the total yield of $\mathrm{AI} 3$ amidase was not calculated

\begin{tabular}{|c|c|c|c|c|}
\hline Stage of purification & $\begin{array}{l}\text { Total enzyme } \\
\text { units } \\
\left(\times 10^{-4}\right)\end{array}$ & $\begin{array}{l}\text { Total } \\
\text { protein } \\
(\mathrm{g})\end{array}$ & $\begin{array}{l}\text { Specific } \\
\text { acetamidase } \\
\text { activity }\end{array}$ & $\begin{array}{l}\mathrm{AI} / \mathrm{A} \dagger \\
\text { transferase } \\
(\%)\end{array}$ \\
\hline $\begin{array}{l}\text { Bacterial suspension } \\
\text { Cell extract after } \\
\text { streptomycin treatment } \\
\left(\mathrm{NH}_{4}\right)_{2} \mathrm{SO}_{4} \text { precipitation: }\end{array}$ & $\begin{array}{l}\text { IIO } \\
\text { IIO }\end{array}$ & $\begin{array}{r}\text { c. } 17 \\
9 \cdot 2\end{array}$ & $\begin{array}{r}60 \\
120\end{array}$ & $\begin{array}{l}\text { ND } \\
\text { ND }\end{array}$ \\
\hline $\begin{array}{l}\text { Vol. supernatant } \\
\text { (ml) }\end{array}$ & & & & \\
\hline $\begin{array}{r}\mathbf{P}_{0-45} \\
\mathbf{P}_{45-55} \\
* \mathbf{P}_{55-65} \\
\mathbf{P}_{65-75} \\
\mathbf{P}_{75-85}\end{array}$ & $\begin{array}{c}27 \\
6 \\
72 \\
3 \\
0.6\end{array}$ & $\begin{array}{l}5.0 \\
0.9 \\
0.5 \\
0.29 \\
0.054\end{array}$ & $\begin{array}{r}54 \\
32 \\
480 \\
105 \\
107\end{array}$ & $\begin{array}{l}0.6 \\
2 \cdot I \\
0.5 \\
0.6 \\
\text { ND }\end{array}$ \\
\hline $\begin{array}{l}\text { Fraction I } 82 \text { (centre of } \\
\text { amidase peak after DEAE- } \\
\text { Sephadex chromatography) }\end{array}$ & I. 54 & 0.0234 & 657 & ND \\
\hline
\end{tabular}

enzyme was also found to be heat-labile at $57.5^{\circ}$ (Fig. r), indicating, at least for this mutant, that the heat inactivation was a characteristic of the amidase protein and not due to interaction with some other variable component in the crude extract.

\section{Purification of the AI amidase}

The amidase from strain PAC 366 was purified from bacteria grown in a total volume of 451 of minimal medium containing lactate $(0.5 \%(\mathrm{w} / \mathrm{v}))$ as carbon source; the recovery of activity at various stages in the purification is shown in Table 4 . The enzyme was assayed by the transferase assay with acetamide as substrate. For some fractions, acyl transferase activity was also measured with 19 mM-acetanilide as substrate. This activity paralleled the acetamidase activity except in ammonium sulphate fraction $P_{45-55}$ where it appeared to have increased in relation to the acetamidase activity. The reason for this anomaly was not discovered. Both activities were eluted in the same fractions from the DEAE-Sephadex column in the final purification step (Fig. 2) at a potassium chloride concentration of approximately $230 \mathrm{mM}$. Subsequent work was done using fractions containing the centre portion of the enzyme peak eluted from the DEAE-Sephadex column.

Sedimentation analysis of the purified enzyme revealed a minor secondary component with a sedimentation constant of $22 S$; the $S_{20, w}$ value determined for the main component was $10.6 \mathrm{~S}$, in agreement with values obtained for the purified A and B amidases (Brown, 1969).

The $\mathrm{AI}$ amidase was tested in immunodiffusion experiments against antiserum to either A or B amidases. In both cases the clearly defined precipitin lines obtained fused completely with those given by purified A and B amidases, indicating that all three proteins were antigenically very similar. Previously, Brown et al. (1969) had found that amidases from some 




Fig. 2. Purification of AI amidase from strain PAC 366 by DEAE-Sephadex chromatography. -.., protein (extinction $280 \mathrm{~nm}$ ); $\square-\square$, acetamide transferase (units $/ \mathrm{ml}$ ); $\mathrm{O}-\mathrm{O}$, acetanilide transferase (units $/ \mathrm{ml}$ ).

Table 5. Enzyme activities of purified AI amidase

\begin{tabular}{|c|c|c|c|c|}
\hline \multirow[b]{3}{*}{ Substrate } & \multirow{2}{*}{\multicolumn{2}{|c|}{ Amide hydrolysis }} & \multicolumn{2}{|c|}{ Acyl transferase } \\
\hline & & & & (umole hydroxa- \\
\hline & $\begin{array}{c}\text { Concentration } \\
(\mathrm{mM})\end{array}$ & $\begin{array}{c}\left(\mu \text { mole } \mathrm{NH}_{\mathrm{s}} / \mathrm{mg}\right. \\
\text { protein } / \mathrm{min})\end{array}$ & $\begin{array}{c}\text { Concentration } \\
(\mathrm{mM})\end{array}$ & $\begin{array}{c}\text { mate } / \text { mg protein } \\
\text { min) }\end{array}$ \\
\hline Acetamide & I6 & $17 \cdot 9$ & 500 & 657 \\
\hline Propionamide & 500 & $32 \mathrm{I}$ & 500 & 590 \\
\hline Butyramide & 500 & $\mathrm{I} \cdot \mathrm{O}$ & 250 & $I \cdot I$ \\
\hline Acetanilide & - & - & 30 & $4 \cdot 7$ \\
\hline
\end{tabular}

of the valeramide-utilizing mutants gave very diffuse precipitin lines with marked spurring with the precipitin lines given by the $\mathrm{A}$ and $\mathrm{B}$ enzymes.

\section{Enzyme activities of the $A I$ amidase}

Specific activity values were determined for the purified enzyme with various amide substrates in both transferase and hydrolase reactions (Table 5). Although inactivation of the purified $\mathrm{A}$ amidase at high dilution makes it difficult to obtain exact specific activity values, it is clear that not only are the specific activity values for the AI enzyme much lower than for the A amidase, but there are also considerable changes in the relative activities towards the different amide substrates. The maximum value for specific acetamide transferase activity obtained for the A enzyme was about I 800 compared with 660 for the AI enzyme. The relative transferase activities of the $\mathrm{AI}$ enzyme towards acetamide, propionamide and butyramide were in the ratio $I \cdot I: I: 0 \cdot 002$, compared with the A amidase where the values were in the ratio $4: 1: 0 \cdot 0 \mathrm{I}$. The relative hydrolase activities of the AI enzyme towards the three amides are in the ratio $I: 18: 0 \cdot 05$, those of the A enzyme are in the ratio $1: 3: 0 \cdot 02$. The acetamide hydrolase activity of the AI amidase was particularly low; the ratio of acetamide transferase to acetamide hydrolase was 39: I for the AI enzyme compared with 4: I for the A amidase. Normally, values for amide hydrolase activity were obtained with amide concentrations of $500 \mathrm{~mm}$ in the assay mixture but concentrations of acetamide above $16 \mathrm{~mm}$ caused inhibition in the rate of acetamide hydrolysis by the AI enzyme. Substrate inhibition 
Table 6. Comparison of $A, B$ and $A I$ amidases: apparent Michaelis constants

$\begin{array}{llccc} & & & \text { Apparent } K_{m} \text { values (mM) } \\ \text { Enzyme reaction } & \text { Substrate } & \text { AI amidase } & \text { A amidase } & \text { B amidase } \\ \text { Amide hydrolase } & \text { Acetamide } & 30 & \text { I } & 2 \\ & \text { Propionamide } & 22 & 2 \text { I } & 6 \\ \text { Acyl transferase } & \text { Acetamide } & 53 & \text { I9 } & \text { I5 } \\ & \text { Propionamide } & 208 & 55 & \text { IO }\end{array}$

of the A and B enzymes by propionamide and acetamide in the transferase reaction has been observed (Brown, I969) but at relatively high amide concentrations (in excess of $500 \mathrm{mM}$ ). The specific activity of the AI enzyme for the transferase activity with acetanilide as substrate was $0.7 \%$ of its activity towards acetamide. Using the pure B enzyme it was possible to detect some activity towards acetanilide in this reaction, the value obtained being about $10 \%$ of that measured for the AI enzyme and therefore $0.03 \%$ of the specific activity of the B enzyme with acetamide as substrate.

Apparent $K_{m}$ values for propionamide and acetamide in both hydrolase and transferase reactions with the AI amidase were determined from Lineweaver-Burk plots and are compared with those obtained for the A and B enzymes in Table 6. The values determined with the $\mathrm{AI}$ amidase were all higher than those obtained with the $\mathrm{A}$ or $\mathrm{B}$ amidase except for propionamide in the hydrolase reaction which gave a similar value with the $A$ and $A I$ enzymes. The apparent $K_{m}$ for hydroxylamine in the transferase"reaction was not determined for the AI enzyme; McFarlane (1967) obtained a value of I $66 \mathrm{~mm}$ with the wild-type enzyme in the presence of $100 \mathrm{~mm}$-acetamide. The concentration of hydroxylamine used in the standard assay mixture ( $500 \mathrm{~mm}$ ) was assumed to be saturating for the $\mathrm{AI}$ amidase.

The ester transferase activities of the $\mathrm{A}$ and $\mathrm{AI}$ amidases are compared in Table 7 . The specific transferase activity of AI amidase with ethyl acetate as substrate was about $I \cdot 3$ times that of the A enzyme. Setting the values for ethyl acetate at 100 in each case, it is clear that the $\mathrm{AI}$ amidase exhibits a much greater activity towards esters having large groups in the alcohol portion of the molecule than do the A or B amidases.

\section{Comparison of peptide fingerprints}

Performic acid oxidized A, B and AI amidases were digested with trypsin, chymotrypsin and a mixture of the two proteolytic enzymes; the peptides produced were separated on paper by electrophoresis and chromatography and the fingerprints thus obtained were compared for all three proteins. All fingerprints prepared from digest of the A protein were indistinguishable from those prepared from the B protein. The only discernible difference was between maps of the neutral (at $\mathrm{pH} 6.5$ ) peptides from the A and AI proteins shown in Fig. 3. The two peptides indicated by arrows were present in digests of one protein but not the other. Peptides ringed with dotted lines were very faint spots; those on the AI map were present in all three types of digest (tryptic, chymotryptic and mixed) and were presumed to have arisen from the slight contamination in the enzyme preparation. The two arrowed peptides were purified in larger yield from several chromatograms using, in all, approximately $30 \mathrm{mg}$ of each protein digest; the same methods of separation were used but papers were more heavily loaded (up to Io $\mathrm{mg}$ digest $/ \mathrm{sheet}$ at a loading of $2 \mathrm{mg} / \mathrm{cm}$ ). After chromatography, the peptides were located by spraying the paper lightly on one side with $0.025 \%$ $(\mathrm{w} / \mathrm{v})$ ninhydrin in absolute ethanol $+2 \mathrm{~N}$-acetic acid, $75+25(\mathrm{v} / \mathrm{v})$ and heating at $80^{\circ}$ for $5 \mathrm{~min}$. The peptides were cut out and eluted with water; they were subjected again to 




A amidase

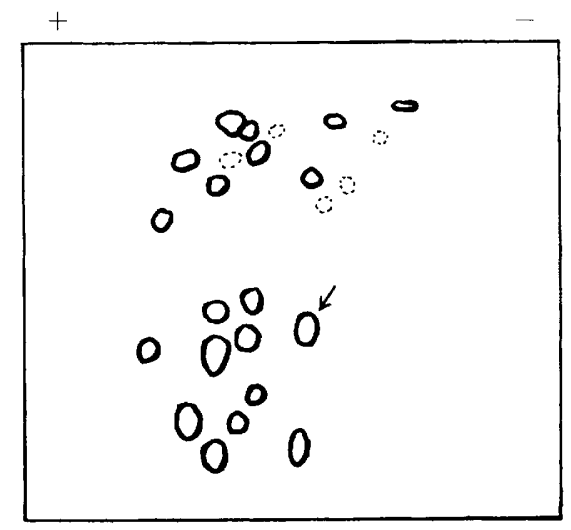

AI amidase

Fig. 3. Fingerprint of neutral peptides obtained after trypsin + chymotrypsin digestion of A amidase purified from strain PAC I 42 and AI amidase purified from strain PAC 366.

Table 7. Relative ester transferase activities of $A I$ and $A$ amidases

\begin{tabular}{lcc}
\multicolumn{1}{c}{ Substrate } & AI amidase & A amidase \\
Methyl acetate (500 mM) & I90 & 72 \\
Methyl propionate (500 mM) & I15 & ND \\
Ethyl acetate (500 mM) & I00 & 100 \\
$n$-Propyl acetate (sat.) & 210 & 67 \\
$n$-Butyl acetate (sat.) & 420 & 147
\end{tabular}

* All activities expressed relative to that for ethyl acetate, which was assigned an arbitrary value of I00. sat. = Saturated solution; ND= not determined.

electrophoresis at $\mathrm{pH}_{3.5}$ to remove the blue ninhydrin complex, eluted and dried in vacuo. Approximately $0.2 \mu$ mole of each peptide was obtained by these methods. After excision of the peptide spots, one AI and one A chromatogram was stained with ninhydrin in the usual way and no spot could be detected on either chromatogram corresponding to the peptide eluted from the other. Amino acid analyses were done on approximately $0.05 \mu$ mole of each peptide and the compositions of the peptides are shown in Table 8 . The equivalent peptide prepared from digests of the $B$ enzyme had the same composition as the peptide from the A protein digest. The identical composition of the peptides with the exception of isoleucine substituting for threonine in the AI peptide strongly suggested that the two peptides were related. To confirm this, sequence analysis was performed on approximately $0.05 \mu$ mole of each peptide and the results are shown in Table 9. It was concluded that the AI amidase differed from wild-type amidase in the substitution of an isoleucine residue for a threonine residue.

\section{DISCUSSION}

Our data indicate that the acetanilide-utilizing mutants produce mutant amidases which hydrolyse acetanilide, enabling the organisms to utilize this compound as a carbon source for growth. Thus, as for the group of butyramide-utilizing mutants described by Brown et al. (1969), an evolutionary step, an expansion of the range of growth substrates, has been 
Table 8. Amino acid composition of peptides obtained from $A$ and $A I$ amidases

\begin{tabular}{ccc} 
& \multicolumn{2}{c}{ Residues/mole } \\
\cline { 2 - 3 } Amino acid & Peptide A amidase* & Peptide AI amidase* \\
Thr & $1 \cdot 10$ & 0.00 \\
Ser & 0.94 & $\mathrm{I} \cdot 00$ \\
Glu & 0.99 & $\mathrm{I} \cdot 02$ \\
Gly & $\mathrm{I} \cdot 06$ & $\mathrm{I} \cdot \mathrm{I} 2$ \\
Leu & 0.96 & $\mathrm{I} \cdot 04$ \\
Arg & 0.95 & 0.90 \\
lleu & 0.00 & 0.92
\end{tabular}

* Values calculated on the basis that the average of the amounts of amino acid present was integral.

Table 9. Amino acid sequences of peptides obtained from $A$ and AI amidases

$\begin{array}{cc}\text { Peptide obtained from } & \text { Amino acid sequence } \\ \text { A amidase } & \text { Ser-Leu-Thr-Gly-Glu-Arg } \\ \text { AI amidase } & \text { Ser-Leu-Ile-Gly-Glu-Arg }\end{array}$

achieved by a mutation in the amidase structural gene. The increased sensitivity of the $\mathrm{AI}$ amidase to heat indicated a less-stable conformation for this enzyme than for the wildtype enzyme; a conformational change could also account for the slight change in electrophoretic mobility shown by the AI amidase on starch gels. The higher values of the apparent binding constants and altered relative activities towards the substrates tested compared with results obtained for the A amidase were further indications that a conformational change had affected the binding site of the AI amidase. McFarlane (1967) suggested that, for the wild-type enzyme, potential esterase activity is limited by steric hindrance caused by the alcohol portion of the ester molecule which is much bulkier than the $-\mathrm{NH}_{2}$ group in the equivalent position in an amide substrate. It was interesting, therefore, that the AI amidase with activity towards an amide with a large $N$-substituent group should show increased esterase activity compared with the A enzyme, particularly towards esters containing large substituent groups in the alcohol portion of the molecule. The altered properties of the amidase purified from strain PAC 366 appear to result from the substitution of an isoleucine residue for a threonine residue present in the A protein. From a consideration of the codon assignments for threonine (ACU, ACC, ACA, ACG) and isoleucine (AUU, AUC, AUA) the substitution must have arisen from a $\mathrm{G}-\mathrm{C} \rightarrow \mathrm{A}-\mathrm{T}$ transition event in the amidase structural gene. The structural and functional alterations of the enzyme protein resulting from this change could have arisen by the removal of the $\mathrm{H}$-bonding potential of the threonine residue or from structural changes arising from the accommodation of the larger substituent non-polar amino acid inside the protein molecule.

Although the procedure for isolation of the acetanilide-utilizing mutants was such that each mutant must have arisen from a separate mutational event it is not possible to say from the data obtained whether or not several different mutations had occurred. However, the results with crude extracts suggested that the amidases produced were similar if not identical. Previously we had concluded that the amidases allowing growth on valeramide were not identical and composed a heterogenous group of proteins (Brown et al. 1969).

The butyramide-utilizing mutants isolated were of two types: those with a mutation in the amidase structural gene producing $\mathrm{B}$ amidases with enhanced activity towards butyramide (Brown et al. 1969), and those with a regulator gene mutation which produced 
constitutively high levels of the wild-type A amidase and were not subject to repression of amidase synthesis by butyramide (Brown \& Clarke, 1970). Those in the latter group were able to grow on butyramide because the wild-type enzyme hydrolyses butyramide at a low but significant rate ( $2 \%$ of that for acetamide). It seemed unlikely that regulatory mutations alone would allow growth on acetanilide. Strain PAC I 42 was unable to grow on acetanilide and no activity towards this amide could be detected in cell-free extracts. Yet strain PAC I42 produces very high levels of wild-type enzyme (up to $10 \%$ of the total cell protein) and is resistant to both catabolite repression and to amide analogue repression by acetanilide. These regulatory properties were, however, an obvious advantage for deriving a structural gene mutant, since even if the specific activity of a mutant amidase were low it would be expected to be produced in large quantities. Previous attempts to obtain acetanilide-utilizing mutants, directly from the wild-type or from the constitutive strain PAC I I (C I I) (used as parent for the butyramide-utilizing strains) had been unsuccessful. The new phenotype, growth on acetanilide, appears therefore to require both regulator and structural gene mutations.

We are grateful to the Medical Research Council for a grant for this research.

\section{REFERENCES}

Brammar, W. J. \& Clarke, P. H. (1964). Induction and repression of Pseudomonas aeruginosa amidase. Journal of General Microbiology 37, 307-3I9.

Brammar, W. J., Clarke, P. H. \& Skinner, A. J. (1967). Biochemical and genetic studies with regulator mutants of the Pseudomonas aeruginosa 8602 amidase system. Journal of General Microbiology 47 , 87-102.

Brown, J. E., Brown, P. R. \& Clarke, P. H. (1969). Butyramide-utilizing mutants of Pseudomonas aeruginosa 8602 which produce an amidase with altered substrate specificity. Journal of General Microbiology 57, 273-295.

Brown, J. E. \& Clarke, P. H. (1970). Mutations in a regulator gene allowing Pseudomonas aeruginosa 8602 to grow on butyramide. Journal of General Microbiology 64, 329-342.

Brown, P. R. (1969). Studies on Wild-type and Mutant Amidase Proteins from Pseudomonas aeruginosa. Ph.D. Thesis, University of London.

Demerec, M., Adelburg, E. A., Clark, A. J. \& Hartman, P. E. (1966). A proposal for a uniform nomenclature in bacterial genetics. Genetics $54,6 \mathrm{I}-76$.

Gray, W. R. (1967a). Sequential degradation plus dansylation. Methods in Enzymology rr, 469-475.

GraY, W. R. (I967b). Dansyl chloride procedure. Methods in Enzymology II, I39-15I.

Hirs, C. H. W. (1956). The oxidation of ribonuclease with performic acid. Journal of Biological Chemistry 2I9, 6II-62I.

Holloway, B. W. (1969). Genetics of Pseudomonas. Bacterial Reviews 33, 419-443.

Kelly, M. \& Clarke, P. H. (I962). An inducible amidase produced by a strain of Pseudomonas aeruginosa. Journal of General Microbiology 27, 305-3I6.

Lowry, O. H., Rosebrough, N. J., Farr, A. L. \& Randall, R. J. (I95I). Protein measurement with the Folin phenol reagent. Journal of Biological Chemistry 193, 265-275.

McFarlane, N. D. D. (1967). Studies on Pseudomonas aeruginosa Amidase. Ph.D. Thesis, University of London.

MCFARlane, N. D. D., Brammar, W. J. \& Clarke, P. H. (I965). Esterase activity of Pseudomonas aeruginosa amidase. Biochemical Journal $95,24 \mathrm{C}-25 \mathrm{C}$.

Michl, H. (I95I). Über Papierelektrophorese bei Spannungsgefällen von $50 \mathrm{~V} / \mathrm{cm}$. Monatshefte für Chemie $82,489-493$.

MilsteIn, C. (1966). The disulphide bridges of immunogiobulin $\kappa$-chains. Biochemical Journal ror, 338-35I.

Woods, K. R. \& WANG, K.-T. (1967). Separation of dansyl amino acids by polyamide layer chromatography. Biochimica et biophysica acta $\mathbf{1 3 3}, 369-370$. 